\title{
Kutatás a participativitás, az önérvényesítés és a könnyen érthető kommunikáció jegyében
}

Jelen tanulmányban egy folyamatban lévő kutatási programot meghatározó négy gondolatkört mutatunk be: önérvényesítés, gondnoksági rendszer kritikája, participatív kutatás, könnyen érthető kommunikáció.

A kutatási program egyik újdonsága és egyben célja az, hogy a kutatási eredményekkel hozzájáruljunk az értelmi sérült személyek önérvényesítő képességének fejlődéséhez. Ezt olyan módon tesszük, hogy őket kérdezzük meg a gondnokság rendszerével kapcsolatban. Másrészt a kutatási programba társkutatóként bevontunk egy olyan személyt, aki maga is egy kisvárosi lakóotthon cselekvőképességet részlegesen korlátozó gondnokság alatt álló lakója. Ezt a fogyatékosságtudományban participatív kutatásnak nevezzük. Maga a kutatás a könnyen érthető kommunikáció módszerének használatával zajlott.

Kulcsszavak: önérvényesités, támogatott döntéshozatal, közvetlen megkérdezés, gondnokság, participativ kutatás, könnyen érthető kommunikáció

Jelen tanulmány „A gondnokságról alkotott vélemény - előny vagy hátrány” című participatív kutatásom alapján készült. A kutatási eredmények első bemutatására 2020-ban került sor a Szegedi Tudományegyetem Juhász Gyula Pedagógusképző Kar Gyógypedagógus-képző Intézet TDK kari fordulóján, ahol 3. helyezést értem el. Az OTDK-n a Pedagógiai, Pszichológiai, Andragógiai és Könyvtártudományi Szekcióban, a Gyógypedagógia elméleti és történeti témakörei II. Tagozatban 2. helyezést értem el. Ebben a cikkben nem a kutatás eredményeit, hanem a kutatás négy fontosabb alappillérét mutatom be. Célom, hogy ezzel egyfajta példát mutassak mindazoknak, akik az értelmi sérült személyekkel közösen az értelmi sérült emberek életének kutatására vállalkoznak.

Ebben a tanulmányban a célcsoport megjelölésére az „értelmi sérült ember” fogalmat használom, ezalatt értem az értelmileg és a tanulásban akadályozott személyeket egyaránt. Az emberi jogi megközelítésből indulok ki. Ezért az értelmi sérülés gyógypedagógiai, illetve orvosi meghatározása a tanulmányban nem releváns.

\section{AZ ÖNÉRVÉNYESÍTÉSRŐL}

Az ENSZ fogyatékossággal élő személyek jogairól szóló egyezménye 3. cikke alapján az értelmi sérült embernek az önérvényesítéshez joga van (fogyatékosságügyi ENSZ egyezmény, 2006). 
Az önérvényesítés mozgalma Edward Roberts nevéhez köthető (Roberts, 2020). Az önérvényesítés angol megfelelője az empowerment. A kifejezés a power (hatalom) szóból ered. Az angol nyelvben a fogalom az eredeti jelentésre utal, ami szó szerint jogi hatalommal való felruházást jelent; engedélyt egy megadott konkrét cél eléréséhez vagy szándék megvalósításához (Rappaport, 1987). „Az empowerment tágabb értelmezésén túl az emancipáció fogalommal operál; a hangsúlyt arra teszi, hogy adott társadalom (közösség) tagjai tudják legjobban, hogy voltaképpen mire is van szükségük" (Budai \& Puli, 2012:7).

Az empowerment egy folyamat, amelyben egyre inkább a kezébe veszi az ember a saját életének irányítását. Tudatosan egyre inkább felelősséget vállal önmagáért. A folyamat belső és külső szegmensekre bontható. A belső folyamat lényege, hogy az ember hisz abban, hogy döntést tud hozni, illetve, hogy meg tudja oldani a problémáit, hogy cselekedni, tenni tud. A külső folyamat pedig abból áll, hogy valóban képes cselekedni, a szerzett tudását a gyakorlatban hasznosítani, új tudást szerezni (Sadan, 2011).

Az önérvényesítés „önismereten alapuló, a saját érdekek felismeréséből következő érdekérvényesítő magatartást jelent, amelynek alapja a kommunikáció" (Horváthné és mtsai, 2011).

A gyógypedagógiában az önérvényesítés azt jelenti, hogy a fogyatékos személyek ki tudnak állni a saját és társaik érdekeiért. Azt is jelenti, hogy megismerik a jogaikat és átadják ezt a tudást a társaiknak is (Bercse \& Czakó, 2019).

Az Önérvényesítők Európai Platformjának európai önérvényesítő szervezetek a tagjai. Rövidítése az EPSA (European Platform of Self Advocates) mozaikszó. Az EPSA az Inclusion Europe szervezet része. Az EPSA 2000 óta képviseli az európai önérvényesítő szervezeteket. Azon dolgozik, hogy erősebbé tegye az európai önérvényesítő mozgalmat: így például 2018 októberében, Brüsszelben az ESPA vezetői képzést tartottak az önérvényesítőknek és családtagjaiknak. A képzés arról szólt, hogy hogyan tudnak beleszólni a politikai életbe európai uniós szinten. A képzés egyik napja az Európai Parlamentben volt, ahol a résztvevők EU parlamenti képviselőkkel tárgyaltak a választójogról. Az EPSA vezetői önérvényesítők. A saját országában mindenki érdekvédelemmel foglalkozik. Jelenleg Bercse László, a magyarországi ÉFOÉSZ társelnöke az EPSA elnöke. A „Halljátok a hangunkat” egy konferencia önérvényesítők számára, amit az EPSA szervez kétévente. A legutóbbi alkalom 2019-ben Grazban, Ausztriában került megrendezésre. Az eseményre 12 országból összesen 150 önérvényesítő és segítő érkezett. A konferencia arról szólt, hogyan tudnak az önérvényesítők részt venni a politikai életben és hallatni a hangjukat úgy, hogy a döntéshozók is meghallják azt. A konferencia során a résztvevők üzeneteket fogalmaztak meg, például: „minden értelmi fogyatékossággal élő embernek legyen választójoga, egész Európában!”; „Aki szavazhat, kapjon könnyen érthető tájékoztatást a választásokról!”; „Szűnjön meg a gondnokság!” (ÉFOÉSZ, 2020).

„A fogyatékos emberek nem jótékonykodás alanyai, hanem jogok birtokosai, önálló akarattal rendelkező autonóm, független személyek. Az állami, kormányzati cselekvéseknek ezért mindenekelőtt azt kell előmozdítaniuk, hogy az intézményrendszer és a társadalom közremüködése ne a fogyatékos emberek helyett történő döntésekre és tevékenységekre irányuljon, hanem arra, hogy a fogyatékos személyek ezeket maguk gyakorolhassák emberi méltóságuk megörzése mellett" (Országos Fogyatékosságügyi Program, 2015). 
Az önérvényesítés jogának a korlátozásaként lehet a cselekvőképesség jogának korlátozását értelmezni. Ha az értelmi sérült személy nem hozhat önállóan döntést, akkor az önérvényesítés sem valósulhat meg. A továbbiakban azt vizsgálom, hogy az önérvényesítés hogyan néz ki a cselekvőképesség tükrében.

\section{A HELYETTES És A TÁMOGATOTT DÖNTÉSHOZATALRÓL}

Jelen tanulmányban a helyettes és támogatott döntéshozatal fogalmának ismertetése azért lényeges, mert utóbbi maga az önérvényesítésnek a támogatása, és amikor participatív kutatótárssal dolgozunk - melyröl részletesebben a következő fejezetben írok -, akkor tulajdonképpen a participatív kutatótárs és én mint kutató éppen ilyen támogatott döntéshozatalt valósítunk meg.

„A helyettes döntéshozatal tulajdonképpen a gondnokság intézményét jelenti, amikor is az adott személyröl azt feltételezik, hogy nem képes megérteni a döntés lehetséges következményeit" (Jakab, 2011:443.).

A támogatott döntéshozatal ezt a helyettes döntéshozatalt hivatott felváltani a magyar jogrendben. Támogatott döntéshozatal esetén a fogyatékos személy által választott bizalmi személy segíti a támogatott személyt a jog előtt is érvényes, az életét érintő kérdések meghozatalában, miközben a támogatott személy cselekvőképességét nem korlátozzák (Ruzsics, 2013).

A cselekvőképesség teljes és részleges korlátozásáról, valamint a helyettes és támogatott döntéshozatalról a témák iránt részletesebben érdeklődő olvasó „A gondnokságról alkotott vélemény - előny vagy hátrány” című TDK-dolgozatomban olvashat (Peszeki, 2021).

A fogyatékos személyek, köztük az értelmi sérült személyek jogait - többek között - a fogyatékosságügyi ENSZ egyezmény határozza meg. Magyarország az elsők között írta alá, majd 2007-ben ratifikálta is, ezáltal az egyezményben leírtak megvalósítását és a megvalósítás ellenőrzését is vállalta (Horváth, 2013).

„A cselekvőképesség minden esetben valamely élő személyhez kötődő, sajátosan humán kompetenciát jelöl: az emberi személy azon képességét, hogy tapasztalatainak és céljainak birtokában, korlátait és lehetőségeit felmérve, az akarás pszichés aktusa révén olyan döntést hozzon, amelynek következményeit felismeri és belátja, rövid és hosszú távú konzekvenciáinak tudatában van, s azért felelősséget vállal. A cselekvőképesség szűkebb kategória az emberi mivolt általános lényegéhez kötött jogképességnél. A jogképesség kategóriája a polgári jogegyenlőség elvének kifejeződése, amely valamennyi élve született, az emberi fajhoz tartozó lényt megillet" (Verdes \& Tóth, 2008:8).

A Polgári Törvénykönyvről szóló 2013. évi V. törvény (Ptk.) a jogi háttere a gondnokság alá helyezésnek. A gondnokság alá helyezés folyamata a döntési képességükben átmenetileg vagy tartósan sérült embereknek a gyámhivatal által kijelölt gondnokon keresztüli segítését szolgálja.

A bíróság cselekvőképességet részlegesen korlátozó gondnokság alá azt a nagykorút helyezi, akinek ügyei viteléhez szükséges belátási képessége - mentális zavara következtében - tartósan vagy időszakonként visszatérően nagymértékben csökkent, és emiatt - egyéni körülményeire, valamint családi és társadalmi kapcsola- 
taira tekintettel - meghatározott ügycsoportban gondnokság alá helyezése indokolt [Ptk. 2:19. § (1)-(2) bek.].

A gondnokság alá helyezésröl orvosi szakvélemény alapján a bíróság hoz határozatot. Ez a határozat nem élethosszig tartó. Mivel az idő múlásával az egyén belátási, valamint mentális képességei változhatnak, így a gondnokság alá helyezést meghatározott időközönként kötelező felülvizsgálni. Ez a felülvizsgálat „a cselekvőképesség részleges korlátozása esetén nem lehet későbbi, mint az ítélet jogerőre emelkedésétől számított öt év; a cselekvőképesség teljes korlátozása esetén nem lehet későbbi, mint az ítélet jogerőre emelkedésétől számított tíz év" [Ptk. 2:29. § (1) bek. a) pont].

A területileg illetékes gyámhivatal a gondnokság alatt álló személy mellé kirendelő határozattal nevez ki gondnokot. A gondnok feladata a gondnokolt képviselete, bevételének, vagyonának kezelése. A gondnoki tevékenységről évente kell beszámolnia, a vagyonkezelést illetően a gondnokság alatt álló vagyoni leltára alapján. A vagyonkezelés az érintett ingó és ingatlan vagyonára, annak kezelésére, bevételeire és kiadásaira vonatkozik. A gondnoki szerepkört minden 18. életévét betöltött, teljes mértékben cselekvőképes személy betöltheti, ha vállalja a tisztséget. Az arra alkalmas személyek közül a szülőket, más hozzátartozókat - akik szükség esetén a személyes gondoskodást is el tudják látni - előnyben kell részesíteni. Nem lehet kirendelni olyan gondnokot, akinek a személye ellen a gondnokolt egyértelmüen tiltakozik. Ha a szülö, hozzátartozó nem alkalmazható, vagy nem vállalja a tisztséget, a gondnokolt számára hivatásos gondnokot kell kirendelni [Ptk. 2:31. § (1)-(3) bek.].

Az a személy válhat hivatásos gondnokká, aki az alábbi feltételeknek eleget tesz: 18. életévét betöltötte, cselekvőképes, büntetlen előéletű magyar állampolgár, akivel szemben a jogszabályokban meghatározott kizáró körülmény nem áll fenn. A hivatásos gondnok személyének további feltétele, hogy legalább középfokú iskolai végzettséggel rendelkezzen, és a rendeletben meghatározott képzést sikeresen elvégezze. A gondnok tevékenységéért díjazásban nem részesül, de az esetlegesen felmerülő költségeinek megtérítését igényelheti. Munkadij csak a hivatásos gondnokot illeti meg [Ptk. 2:31. § (5) bek.].

Számos kutatás, tanulmány született már a gondnokság rendszerével kapcsolatban, azonban ezen munkák közös jellemzője, hogy nem a gondnokság alá helyezett személyeket kérdezték (Gazsi, 2016; Kaló \& Horváth, 2019). Kiemelkedően fontosnak tartom, hogy hangot adjunk maguknak, az értelmi sérült személyeknek is. Éppen ezért kutatásomban a gondnokolt személyeket kérdeztem meg. Ugyanakkor a kutatás megkezdésekor olyan félelem merült fel bennem, hogy a lakóotthonban élő értelmi sérült személyek nem szívesen osztanák meg és részleteznék egy ismeretlen személlyel a történeteiket, élményeiket. Tartottam attól is, hogy nem biztos, hogy át fogom tudni látni a gondnokság bonyolult rendszerét. A harmadik nehézséget a könnyen érthető interjúk elkészítése okozta: ugyanis a lakóotthonban élő értelmi sérült személyek eltérő képességekkel rendelkeznek, így szükséges volt az is, hogy az interjúkérdések könnyen érthető formában is rendelkezésre álljanak. Ezen okoknál fogva, valamint témavezető tanárom javaslatára elgondolkodtam a participatív kutatás lehetőségén. 


\section{PARTICIPATÍV KUTATÁS}

Amikor a sérült személyek önállóan kutatnak, azt emancipatív kutatásnak, amikor viszont ép és sérült személyek közösen kutatnak, azt participatív kutatásnak nevezik. Participatív kutatás esetében már maga a kutatási folyamat is változást hozhat az érintett személyek hatalommal való felruházása által (Katona és mtsai, 2019).

A participatív kutatásoknak az alapelve, hogy minden embernek joga van beleszólni azokba a kutatásokba, kérdésekbe, amelyek az ő életére vonatkoznak. Ez a „semmit rólunk nélkülünk!” elv, ami a fogyatékosságügyi ENSZ egyezmény egyik legfontosabb értéke. Ennek a szemléletnek a megjelenése a tudományos munkában elősegíti a minél teljesebb társadalmi integrációt (Heiszer, 2011). A participatív kutatótárs megbízható informátor, akinek önálló, megalapozott véleménye van a saját és társai életét érintő kérdésekről (Marton \& Könczei, 2009).

A participatív kutatás lényege, hogy magában a kutatás folyamatában nem egyedül veszek részt, hanem bevonok a kutatás munkálataiba egy értelmi sérült személyt is. Ezáltal a kutatásban nem csak interjúalanyként jelennek meg értelmi sérült személyek, hanem kompetens szakértőként, egyenrangú félként is.

A kutatótárs részéről feltétel, hogy motivált legyen. Előnyös lehet, ha már van érdekvédelmi vagy önérvényesítő tapasztalata (Sándor, 2018). Cziráki Zsolttal először a 2019/20-as egyetemi tanév őszi félévében találkoztam. Ebben a félévben részt vettem az "Önkéntes munka értelmileg akadályozott személyekkel" című kurzuson, ahol többek között a gondnokság rendszeréről is szó esett. Mivel úgy éreztem, Zsolttal számos kérdésben egyetértünk, azonos értékrenddel rendelkezünk, így őt kértem fel participatív kutatótársamnak.

Zsolt megbízható, hiteles információkkal rendelkezik, hiszen maga is egy magyarországi, kisvárosi lakóotthonban él. Ahogy az önmagáról készített jellemzésben is olvasható, „vallja és hiszi is, hogy tudatosan képviselheti önmagát és a hasonló sorstársait is, illetve, hogy méltón és büszkén érvényesítheti szabadon az akaratát és így önmagát és közösségét is jól képviselheti. Participatív oktatóként segíti az egyetemi hallgatókat is a könnyen érthető kommunikációra történő felkészítésben" (Cziráki, 2020: o.n.).

A kutatás az első pillanattól kezdve participatív módon zajlott. Közösen határoztuk meg a kutatás célját és a kutatási kérdéseket, majd ezeknek megfelelően dolgoztuk ki a kutatás módszertanát. Ezalatt kölcsönösen tanulhattunk egymástól. A kapcsolattartás a vírushelyzet miatt többnyire az online térben zajlott, hang- és videohívásokon keresztül, valamint írásban kommunikáltunk egymással. A kommunikáció meglepően gördülékenyen működött ebben a formában is. Elöre megbeszélt alkalmakon, video- és hanghívás segítségével írtuk meg közösen a kutatásetikai elveknek megfelelő dokumentumokat. Tájékoztató levelet írtunk a kutatás céljáról és a megszólított személy feladatairól a kutatásba bevonni szándékozott személyek gondnokainak és maguknak a lakóotthon lakóinak is, utóbbi csoportnak könnyen érthetően. Az adatkezelési hozzájáruló nyilatkozatot a cselekvőképességet korlátozó gondokság alatt álló személyek helyett a gondnokok írták alá. Ugyanakkor az önérvényesítés és a „semmit rólunk nélkülünk” elvre figyelemmel fontosnak tartottuk, hogy a lakóotthonban élő értelmi sérült felnőttek is hozzájáruljanak az adatkezeléshez még akkor is, ha jogi értelemben ez nem az ő lehetőségük. Ezekben a nyilatkozatokban írásos hozzájárulást kértünk ahhoz, hogy az interjúba bevont személyektől 
gyűjtött adatokat és információkat kutatási céllal, a személyiségi jogok védelmére figyelemmel, anonim módon felhasználhassuk.

Elkészítettük az interjúkérdéseket is. Ezeket természetesen könnyen érthető módon állítottuk össze, a célcsoportnak megfelelő nyelvezettel. A könnyen érthető kommunikáció használatára a következő fejezetben térek ki.

Barthel (2004:185-186) szerint „A kommunikációjukban gátolt emberek megkérdezése során hasznos lehet, ha jelen van egy harmadik személy is, akivel a kérdezett bizalmas kapcsolatban van. Ö segíthet 'lefordítani' a számukra nehezebben értelmezhető közléseket. További előnye lehet, hogy az interjúalanynak biztonságérzetet ad jelenléte."

Ezt erősíti meg Katona (2013) is, aki szerint az interjúk felvétele során a kommunikációt segítheti, ha jelen van egy harmadik személy, például éppen a participatív kutatótárs, aki „tolmácsol”, azaz egyfajta kommunikációs hidat képez a kutató és a kutatás alanyai között.

Az online interjúk alatt Zsolt biztosította az internetkapcsolatot, az interjúkhoz szükséges eszközöket, és ő biztosította az interjúra alkalmas teret is. Az interjúk alatt, míg én egyedül voltam, a vonal másik végén Zsolt, illetve az interjúalany volt jelen. Kiegészítéseivel, javaslataival biztosította az eredményes kommunikációt. Az interjúk alatt, ha az interjúalany bizonytalan volt, Zsolt egy-egy biztató szóval, rávezető kérdésekkel garantálta az interjúalanyok közvetlenségét, a kérdésekre adott válaszok pontosságát. Ez számomra hatalmas segítséget jelentett. Végül minden interjú után közösen átbeszéltük a számomra kevésbé érthető válaszokat.

Zsolt az elemzés folyamatában is hasznos kutatótársként volt jelen. Véleményével, javaslataival, meglátásaival nagyban segítette a kutatás eredményeinek megfogalmazását is.

\section{A participatív kutatás és az önérvényesítés kapcsolata}

A participativ kutatás fontos eleme a feltárt tudás megosztásában való egyenrangú részvétel is (Katona és mtsai, 2019). Ugyanakkor az értelmi sérült kutatótárs verbális képességei, legalábbis kezdetben feltételezhetően elmaradnak a tudományos kutatás során elvárt nyelvi szinttöl. Ezért kiemelten fontos a minél hatékonyabb együttműködés érdekében, hogy a kutató alkalmazkodjon a kutatótársa nyelvi szintjéhez. Ennek meg kell jelennie mind az egyszerúbb nyelvi szerkezetek, mind az érthető szókincs használatában. Az értelmi sérült személyekkel való hatékony kommunikálás eszköze lehet a könnyen érthető kommunikáció, amelynek szóbeli és írásbeli változatát is érdemes érvényre juttatni.

2021. január 17-én a IX. Neveléstudományi és Szakmódszertani Konferencián lehetőségünk volt egy 15 perces előadásban bemutatni a kutatásunkat. Ezt szintén participatív módon, Zsolttal és témavezető tanárommal, dr. Horváth Péter Lászlóval közösen tettük meg. Az előadásnak nagy sikere volt. A zsürinek és a többi előadónak egyaránt elnyerte a tetszését a participatív előadásmód. Felülmúlhatatlan érzés volt ilyen módon előadni, hiszen ez is a participatív kutatásunk hitelességét támasztotta alá. A közös előadással hozzájárulhattam participatív kutatótársam önérvényesítéséhez is (Peszeki \& mtsai, 2021). 


\section{A KÖNNYEN ÉRTHETŐ KOMMUNIKÁCIÓRÓL}

Az értelmi sérült személyek közvetlen megkérdezésének nehézsége, hogy a bonyolult kifejezéseket, az idegen szavakat, hosszú kérdéseket igen nehezen tudják értelmezni. Minden esetben alkalmazkodnunk kell tehát az interjúalany nyelvi képességeihez. A kérdéseket úgy kell módosítani, átírni, hogy azok a résztvevők számára is könnyen érthetök legyenek.

A fogyatékosságügyi ENSZ egyezmény az akadálymentes kommunikáció fogalmába sorolja a taktilis kommunikációt, a Braille-nyomtatást, a hozzáférhető multimédiát, a nagyméretü betűkkel történő nyomtatást, valamint az írott és a hangzó, az egyszerü (vagyis könnyen érthetö) szövegeket, a felolvasást, illetve az augmentatív kommunikációt, beleértve a hozzáférhető kommunikációs és információs technológiákat és a kommunikáció egyéb alternatív módozatait (fogyatékosságügyi ENSZ egyezmény, 2006).

Bár a könnyen érthető üzenet készítése szabályrendszerének egységesítésére számos nemzetközi kísérlet történt, a legmeghatározóbb az Inclusion Europe és az ÉFOÉSZ által 2009-ben kiadott szabályrendszer (Inclusion Europe \& ÉFOÉSZ, 2009). Hazai szinten elsősorban ez az alapja a könnyen érthető produktumok készítésének, így participatív kutatótársammal ezen szabályok mentén dolgoztuk ki az interjú könnyen érthető kérdéssorát.

A könnyen érthető formában készült interjúkérdések első változatáról hamar kiderült, hogy bár Zsolttal közösen írtuk, ismerve az interjúalanyok képességeit, mégsem bizonyult megfelelőnek az interjúalanyok számára. Ebből adódóan az első két interjú - melyeket egy napon vettünk fel - kicsit hosszabbak voltak, mert a kérdéseket nehezebben értették. Ezen a ponton is segítségemre volt Zsolt, aki a bizonytalan, nehezebben érthető kérdéseknél könnyebben érthető megfogalmazást ajánlott. Így az interjúalanyok eredményesen tudtak válaszokat adni a kérdéseinkre. A két interjú után Zsolttal egyeztettünk arról, hogy mit és hogyan kellene módosítani a kérdéseken, és a következő helyzetekben már ezt a módosított kérdéssort használtuk. Ezt a kutatásunk során használt, félig strukturált interjú módszere engedte meg. A félig strukturált interjú módszerének a lényege, hogy elöre megírt kérdések alapján zajlik az interjú, de amennyiben az interjú menete megkívánja, a kérdéssortól eltérhet az interjúztató, új vagy részletesebb kérdéseket tehet fel (Lehota, 2001).

Participatív kutatótársammal végül minden interjú után megbeszéltük a tapasztalatokat, és szükség esetén újra egyszerüsítettünk a kérdéseken.

A könnyen érthető kommunikáció fontosságát azonban nem csak a kutatási eszköz kidolgozása és alkalmazása során nyert tapasztalatokkal lehet alátámasztani. Az interjúalanyok számos esetben jelezték, hogy igényt tartanának könnyen érthető anyagokra. Arra a kérdésre, hogy az érintett interjúalanyok min változtatnának a gondnokság rendszerében, a gondnokság lemondásának vágyán kívül több olyan javaslatot is kaptunk, hogy könnyen érthető segédletek, tájékoztatók, útmutatók segítségével az értelmi sérült személyek élete megkönnyíthető lenne. Ennek alátámasztására idézek az egyik interjúból:

77: kérdező: „És ezeket a gyógyszereket, amiket kaptál, ki váltotta ki? Te, vagy valaki más?"

78: válaszoló: „Nem, a nevelő. Vagy a gondnok, vagy a nevelő.” 
79: kérdező: „Rendben, köszönöm szépen. És ki tudnád-e váltani? Tudod-e a folyamatát, hogy hogyan kell?"

80: válaszoló: "Ha elmagyaráznád, biztos."

81: kérdező: Tehát akkor, ha lenne hozzá információd, akkor te magad is meg tudnád ezt csinálni, igaz?"

82: válaszoló: „Hát igen, ha elmondanák, akkor biztos, hogy ki tudnám váltani.”

(részlet a 9. interjúból)

\section{A könnyen érthetö kommunikáció és az önérvényesítés kapcsolata}

„Mivel az információ érték, birtoklása hatalmat ad birtokosa kezébe” (Slíz, 2012:14). „Az információ hatalom! Az információkhoz való egyenlő esélyű hozzáférés, az információk megértése feltétele annak, hogy tájékozódni tudjunk a világ dolgaiban. A tájékozódás során szerzett információkat felhasználjuk mindennapi döntéseink során. Amikor magunk hozunk döntéseket, akkor magunk rendelkezünk az életünk felett. Ezt nevezzük önrendelkezésnek. Vannak olyan emberek, akik kirekesztődnek az információkból, így nincs hatalmuk a saját életük felett. A hatalommal való felruházás egyik eszköze a könnyen érthető kommunikáció" (Horváth, 2020:21.).

Az önérvényesítők a könnyen érthető kommunikáció kiemelt szereplői. Ők azok, akik egyfelől igénylik a könnyen érthető információkat. Másfelöl az önérvényesítők között találunk olyan személyeket is, akik könnyen érthető információkat készítenek, és adott esetben képesek a mások által készített könnyen érthető információk könynyen érthetőségének az ellenőrzésére. Ilyen módon az önérvényesítők a könnyen érthető kommunikáció oktatásának egyik célcsoportját alkotják, illetve ők maguk is képessé válthatnak az önérvényesítés és a könnyen érthető kommunikáció oktatására (Horváth, 2020).

A könnyen érthető kommunikáció fontosságáról számos előadást hallhattunk az elmúlt években. Ilyen volt például az ÉFOÉSZ Önérvényesítő Csoportjának előadása a könnyen érthető kommunikáció és önérvényesítés témában. Sallai llona, az Önérvényesítő Csoport egyik alapító tagja az önérvényesítők munkáját és céljait mutatta be és hívta fel a figyelmet arra, hogy az önérvényesítés módszereinek átadásával lehet az érintetteket megtanítani a saját érdekeik képviseletére. Bercse László, az ÉFOÉSZ társelnöke az elöadáson a könnyen érthető kommunikáció alapelveit ismertette, szerinte a könnyen érthető hírek és cikkek elterjedésével a fogyatékossággal élők minél több és érthetőbb információhoz férhetnek hozzá, ami elengedhetetlen eszköze annak, hogy a társadalom aktív szereplőivé váljanak.

\section{ÖSSZEGZÉS}

Jelen tanulmány középpontjába a participatív kutatás, az önérvényesítés és a könynyen érthető kommunikáció elméletének és a gyakorlatának összekapcsolását állítottam.

A támogatott döntéshozatalról mint az önérvényesítés egyik lehetőségéről a kutatásba bevont értelmi sérült személyek kevés és nem feltétlenül mély ismeretekkel rendelkeznek. Ugyanakkor megfogalmazták igényüket arra vonatkozóan, hogy szí- 
vesen olvasnának könnyen érthető anyagokat például a pénzkezelésröl és a mindennapi tevékenységekről. Ha ezeket az anyagokat elkészítenénk, úgy a participatív kutatótásammal immáron participatív oktatótársként tréningeket, képzéseket, előadásokat tarthatnánk a lakóotthon lakóinak. Bízom abban, hogy erre lesz lehetőségem a jövőben.

\section{Irodalom}

a Fogyatékossággal élő személyek jogairól szóló ENSZ egyezmény, 2006

az Országos Fogyatékosságügyi Programról (2015-2025) szóló 15/2015. (IV. 7.) OGY határozat a Polgári Törvénykönyvröl szóló 2013. évi V. törvény

Barthel B. (2004). Értelmileg súlyosan akadályozott és halmozottan sérült emberek véleményének kikérése. Gyógypedagógiai Szemle, 32.3:184-190.

https://epa.oszk.hu/03000/03047/00026/pdf/EPA03047_gyosze_2004_3_184-189.pdf Letöltés ideje: 2021.03.08.

Bercse L. \& Czakó T. (2019). Önérvényesités és önálló életvitel. Kézirat.

Budai I. \& Puli E. (szerk.) (2012). Együttmüködés a szociális szolgáltatásokban. Széchenyi István Egyetem, Györ.

Cziráki Zs. (2020). Gondolatok az önérvényesítésröl a participatív kutatással kapcsolatban. Kézirat.

ÉFOÉSZ (2020): Az ÉFOÉSZ honlapja. https://efoesz.hu/ Letöltés ideje: 2021.03.08.

Gazsi A. (2016). A támogatott döntéshozatal elve és gyakorlata. Esély, 2016.2:62-92.

Heiszer K. (2011). Új fogyatékosságtudományi kutatási irányzatok Williams szindrómás fiatalokkal. ELTE Bárczi Gusztáv Gyógypedagógiai Kar, Budapest.

Horváth P. L. (2013). Társadalmi integráció és fogyatékosságügyi politika. In Zászkaliczky P. (szerk.), A társadalmi és az iskolai integráció feltételrendszere és korlátai. ELTE Bárczi Gusztáv Gyógypedagógiai Kar, Budapest. 11-57.

Horváth P. L. (2020). A könnyen érthetö kommunikációs képzési programok képzésfejlesztésének története Magyarországon a fogyatékossággal élő személyek jogairól szóló ENSZ egyezmény tükrében. (Doktori értekezés.) Eszterházy Károly Egyetem Neveléstudományi doktori iskola, Eger.

Horváthné Somogyi I., Danó R. \& Tóth Sz. (2011). Támogatott döntéshozatal. Az ÉFOÉSZ modellkísérleti programjának tapasztalatai. Inclusion International - ÉFOÉSZ, Budapest.

Inclusion Europe \& ÉFOÉSZ (2009a). Információt mindenkinek! A könnyen érthető kommunikáció európai alapelvei. Inclusion Europe - ÉFOÉSZ, Brüsszel - Budapest.

Jakab N. (2011): A támogatott döntéshozatal elméleti és gyakorlati kérdései Kanadában. Sectio Juridica et Politica, 29.2:435-459.

Kaló C. G. \& Horváth P. L. (2019). Látkép a támogatott és a helyettes döntéshozatal helyzetéröl. Fogyatékosság és Társadalom. 2019.2:100-119. https://doi.org/10.31287/FT. hu.2019.2.7

Katona V. (2013). Felnőtt értelmi fogyatékos személyek életútjának feltérképezése. In Zászkaliczky P. (szerk.), A társadalmi és az iskolai integráció feltételrendszere és korlátai. ELTE Eötvös Kiadó, Budapest. 117-177.

Katona V., Cserti-Szauer Cs. \& Sándor A. (szerk.) (2019). Együtt oktatunk és kutatunk! Inkluzív megközelités a felsőoktatásban. ELTE Eötvös Kiadó, Budapest. 113-174.

Központi Statisztikai Hivatal (2012). Statisztikai Tükör. VI.45. Központi Statisztikai Hivatal, Budapest.

Lehota J. (2001). Marketingkutatás az agrárgazdaságban. Mezőgazda Kiadó, Budapest.

Marton K. \& Könczei Gy. (2009). Új kutatási irányzatok a fogyatékosságtudományban. In Fogyatékosság és társadalom 2009.1:5-12.

Peszeki D. (2021): A gondnokságról alkotott vélemény: elöny vagy hátrány? (TDK-dolgozat.) SZTE Juhász Gyula Pedagógusképző Kar Gyógypedagógus-képző Intézet, Szeged.

Peszeki D., Cziráki Zs., Horváth P. L. (2021). A gondnokság intézménye az érintettek szempontjából: Előny vagy hátrány? In Karlovitz János Tibor (szerk.), IX. Neveléstudományi és Szakmódszertani Konferencia (2021): Program. Tartalmi összefoglalók. Vzdelávacia, výskumná a metodická konferencia. 71. http://www.irisro.org/9programabsztraktNSZK2021.pdf Letöltés ideje: 2021.03.09. 
Rappaport, J. (1987). Terms of empowerment/exemplars of prevention: Toward a theory of community psychology. American Journal of Community Psychology, 15.2:121-145. https:// doi.org/10.1007/BF00919275

Roberts, E. (2020). Az önérvényesítés mozgalmának atyja, Ed Roberts élete és munkássága. https://artsandculture.google.com/exhibit/VwLy4PBo_Ty9Jg Letöltés ideje: 2021.03.08.

Ruzsics I. (2013). A kitagolás folyamatai Európában és Magyarországon. http://www.jgypk.hu/ mentorhalo/tananyag/kitagolas/index.html Letöltés ideje: 2021.03.08.

Sadan, E. (2011). Közösségi tervezés és empowerment. ELTE Társadalomtudományi Kar, Budapest. https://docplayer.hu/36303097-Kozossegi-tervezes-es-empowerment.html Letöltés ideje: 2021.03.08.

Sándor A. (2018). „Az együttgondolkodásból fakadó többlettudás az értelme.” Az inkluzív kutatás módszertana egy fogyatékosságtudományi kutatás tapasztalatai tükrében. Gyógypedagógiai Szemle, 46.1:12-32.

Slíz M. (2012). Az információ hatalom. Az információ hétköznapi metaforái. AETAS Történettudományi folyóirat, 27.4:13-21.

Verdes T. \& Tóth M. (2008): A per tárgya. ELTE BGGYK - ELTE Eötvös Kiadó, Budapest.

\section{További olvasmány az ELTE Bárczi Gusztáv Gyógypedagógiai Kar kiadásában}

\section{Hogy értsük egymást}

Ez a kötet olyan tanulmányokat tartalmaz, amelyek segítséget nyújthatnak az intellektuális képességzavarral élő személyek kommunikációfejlesztése során.

A kötet első részében szereplő tanulmányokat a gyakorlatban dolgozó kollégákon kívül BA képzésben részt vevő, értelmileg akadályozottak pedagógiája és logopédia szakos hallgatók figyelmébe ajánljuk. Az írások foglalkoznak az augmentatív és alternatív kommunikációval, a korai és iskoláskori fejlődés-fejlesztés szempontjaival, az iskolai fejlesztésre vonatkozó fejezet pedig nemcsak konkrét módszerekkel és feladatokkal, hanem az egyes szintek (helyi tanterv, tematikus

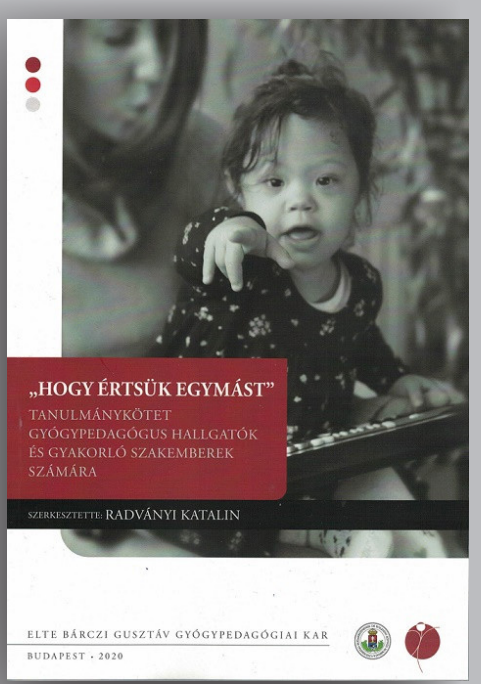
terv) konkrét példáinak bemutatásával is segíti az eligazodást.

A kötet második részében szereplő tanulmányok neurokognitív és pszicholingvisztikai szempontok oldaláról közelítve tárgyalják a nyelvi zavarok és genetikai szindrómák kutatását, melyek az MA képzésben tanulók számára is hasznos és új információkat tartalmaznak.

A kötet szerkesztője Radványi Katalin, szerzői között találjuk Kálmán Zsófiát, Juhász Ágnest, Radványi Katalint, Pál-Horváth Ritát, Földesiné Czövek Klárát, Csépe Valériát és Pléh Csabát. 